\title{
Optimalisasi Parameter Bandwidth dan Time Echo untuk Mengurangi Susceptibility Artifacts dan Chemical Shift pada MRI
}

\author{
Suryani Dyah Astuti ${ }^{1,2 *}$, Nur Vita Indri Astutik ${ }^{1}$, Akhmad Muzamil $^{2}$ \\ ${ }^{1}$ Departemen Fisika, Fakultas Sains dan Teknologi, Universitas Airlangga \\ ${ }^{2}$ Pasca Sarjana TeknoBiomedik, Universitas Airlangga \\ e-mail: ${ }^{1,2 *}$ suryanidyah@gmail.com,, vita.indrias@ gmail.com, ${ }^{2}$ muzamilaaakhmad@gmail.com
}

\begin{abstract}
Abstrak
Telah di lakukan penelitian yang berjudul Optimalisasi Parameter Bandwidth dan Time Echo untuk Mengurangi Susceptibility Artifacts dan Chemical Shift. Tujuan dari penelitian ini adalah untuk mengetahui pengaruh Bandwidth (BW) dan Time Echo (TE) pada MRI Shoulder serta mengetahui nilai variasi Bandwidth dan Time Echo yang optimal untuk mengurangi Susceptibility Artifacts dan Chemical Shift. Penelitian ini di lakukan di RSU Haji Surabaya dengan Pesawat MRI 1,5 Tesla, parameter Bandwidth $170 \mathrm{~Hz} / \mathrm{Px}, 190 \mathrm{~Hz} / \mathrm{Px}$ dan $210 \mathrm{~Hz} / \mathrm{Px}$ dengan variasi TE 16s dan 20s pada pembobotan T2 Medic potongan axial terhadap 4 pasien. Analisa data dilakukan secara kuantitatif dengan menggunakan metode Region of Interest (ROI) pada komputer MRI kemudian dilakukan analisis Signal to Noise Ratio (SNR) dan Contrast to Noise Ratio (CNR) serta analisis terhadap Susceptibility Artifacts dan Chemical Shift. Variasi Time Echo dan bandwidth berpengaruh signifikan terhadap nilai SNR dan CNR pada hasil citra T2 Axial Gradient Echo MRI Shoulder. Pengaruh kedua variasi tersebut adalah semakin kecil nilai TE dan BW didapatkan SNR yang meningkat. Jika TE diperbesar maka didapatkan CNR yang meningkat. Kualitas citra optimal yang dapat menghasilkan keadaan patologis ditentukan dengan meningkatnya nilai CNR dan nilai artefak yang menurun. Sehingga Pada penelitian ini kombinasi antara 2 variabel tersebut dapat menentukan citra optimal pada TE $20 \mathrm{~ms}$ dan BW $210 \mathrm{~Hz} / \mathrm{Px}$.
\end{abstract}

Kata Kunci: Bandwidth, TE, Susceptibility Artifacts, Chemical Shift, MRI Shoulder

\begin{abstract}
Research has been conducted under titled Optimizing Image Axial Sequence T2 Gradient Echo with Bandwidth and Time Echo Variations in the MRI Shoulder to Reduce Susceptibility Artifacts and Chemical Shift. The purpose of this study is to determine the influence of Bandwidth (BW) and Time Echo (TE) on MRI Shoulder and to know variation value of the optimal Bandwidth and Time Echo to reduce Susceptibility Artifacts and Chemical Shift. This research was conducted at Haji General Hospital Surabaya use 1.5 Tesla MRI. This study used variation of Bandwidth $170 \mathrm{~Hz} / \mathrm{Px}$, $190 \mathrm{~Hz} / \mathrm{Px}$ and $210 \mathrm{~Hz} / \mathrm{Px}$ velocities and also used a variation of TE $16 \mathrm{~s}$ and $20 \mathrm{~s}$ on weighting T2 Medic axial pieces for 4 patients. Data analysis was used quantitatively by using Region of Interest (ROI) method on computer MRI then analyzed Signal to Noise Ratio (SNR) and Contrast to Noise Ratio (CNR) and analysis of Susceptibility Artifacts and Chemical Shift. Time Echo and bandwidth variations significantly influence the SNR and CNR values on the citra T2 Axial Gradient Echo MRI Shoulder. The influence of both variations is the smaller the value of TE and BW obtained from increasing SNR. If TE is enlarged then the CNR is increased. The citra optimal quality which can produce pathological state is determined by increasing CNR value and decreasing artefact value. So in this study the combination of these two variables can determine the citra optimal on TE 20ms and $B W$

$\mathrm{Hz}$

$P x$.
\end{abstract}




\section{PENDAHULUAN}

Magnetic Resonance Imaging (MRI) merupakan alat radiodiagnostik yang berfungsi untuk menghasilkan rekaman potongan gambar penampang tubuh manusia dan jaringan lunak secara detail. Pada MRI terdapat parameter dan sequence yang dipilih untuk menghasilkan kualitas citra yang terbaik dalam melihat patologi pada tubuh manusia serta dapat mengurangi adanya artefak. Artefak merupakan gangguan pada gambar yang bukan termasuk anatomi manusia. Susceptibility Artifacts dan Chemical Shift merupakan artefak yang sering ditemui apabila terdapat kekurang telitian pada saat proses screening. Penelitian sebelumnya menggunakan parameter Bandwidth (BW) dan sequence Short Tau Inversion Recovery (STIR) dapat mengurangi adanya Susceptibility Artifacts, tetapi membutuhkan waktu yang lama untuk menghasilkan suatu citra. Pada penelitian ini menggunakan variasi Bandwidth (BW) dan Time Echo (TE) serta menggunakan Sequence Gradient Echo. Tujuan penelitian ini yaitu Mengetahui pengaruh BW dan $T E$ dengan sequence Gradient Echo serta mengetahui nilai BW dan TE yang optimal untuk mengurangi artefak Susceptibility Artifacts dan Chemical Shift

\section{TINJAUAN PUSTAKA \\ 2.1 Magnetic Resonance Imaging (MRI)}

Magnetic Resonance Imaging (MRI) merupakan alat radiodiagnostik yang berfungsi untuk menghasilkan rekaman potongan gambar penampang tubuh manusia dengan menerapkan prinsip resonansi magnetik proton atom hidrogen dengan medan magnet eksternal dan frekuensi radio (RF). Pemanfaatan medan magnet dan gelombang radio frekensi untuk menghasilkan suatu gambar lebih aman digunakan karena tidak menggunkaan sinar- $X$ yang menyebabkan radiasi ionisasi yang berbahaya [1]

MRI mempunyai kelebihan diantaranya yaitu memberikan gambaran jaringan lunak yang sangat jelas dibandingkan dengan alat penegakan diagnosa lainya dan dapat membuat potongan koronal, sagital, aksial dan oblik, sehingga anatomi dan patologi jaringan tubuh dapat dievaluasi secara detail [2] Beberapa komponen utama dalam sistem MRI, yaitu
- Magnet utama untuk memproduksi medan magnet yang besar dan kuat,

- Pemancar frekuensi radio dan koil penerima, yang mengeksitasi dan mendekteksi sinyal MR,

- Gradien Medan magnet (terdiri atas $\mathrm{x}, \mathrm{y}, \mathrm{z})$ untuk melokalisasi sinyal MRI,

- Sistem computer untuk mengendalikan parameter dan menyimpan dokumen.

- Meja pasien untuk tempat pemeriksaan pasien. [3]

\subsection{Prinsip Dasar MRI}

MRI memanfaatkan momen magnetik yang terdapat dalakm tubuh manusia, setiap inti atom memiliki momen magnetic inti atom yang sebanding dengan dengan vektor momentum angular spin [4]

$\vec{\mu}=$

dimana "rasio gyromagnetic" $\gamma$ merupakan karakteristik konstan setiap nuklida. Sedangkan Besar momen Magnetik

$$
=\overline{1}=\sqrt{(1+1)}
$$

dimana I adalah nomor kuantum spin yang nilainya berbeda untuk setiap atom. Dalam prinsip MRI, untuk membangkitkan resonansi magnetic, inti atom tidak boleh memiliki nilai I $=0$. Dalam tubuh manusia terdapat banyak atom diantaranya ${ }^{1} \mathrm{H},{ }^{13} \mathrm{C},{ }^{19} \mathrm{~F},{ }^{23} \mathrm{Na}$ dan ${ }^{31} \mathrm{P}$ yang tidak memiliki I sama dengan 0 , tetapi hanya atom Hidrogen yang memiliki pelimpahan terbesar dalam tubuh manusia. Ada 3 prinsip yang mendasari MRI yaitu Fase Presesi, Fase Resonansi dan Fase Relaksasi. [5]

Medan magnet besar MRI disebut (B0) yang memberikan pengaruh pada arah momen magnetic atom- atom. Sebelum mendapat pengaruh dari medan magnet, atom-atom hidrogen tersusun secara acak. Setelah mendapat pengaruh medan magnet (pasien dimaasukkan kedalam koil MRI) maka atomatom pada pasien tersebut akan berpresesi, mensejajarkan arah nya sesuai dengan pengaruh medan magnet dan mengakibatkan spin berlwanan arah (anti parallel) dan searah medan magnet (parallel). Fase ini disebut Fase Presesi. Gambar 2.1

Torsi ( $\tau$ ) merupakan perkalian silang lengan momen magnetic dengan medan magnet sehingga, 


$$
\frac{\Delta}{\Delta}=\mu \times B
$$

Menurut persamaan ini, spin akan berpresesi pada Frekuensi Larmor, $\omega$ yang berbanding lurus dengan kekuatan medan eksternal, Di bawah pengaruh suatu $B_{0}$ medan magnet eksternal, berpresesi terhadap arah medan pada frekuensi Larmor, yang sebanding dengan $\mathrm{B}_{0}$.

$$
\omega ?=\frac{2}{2}=2 ?
$$

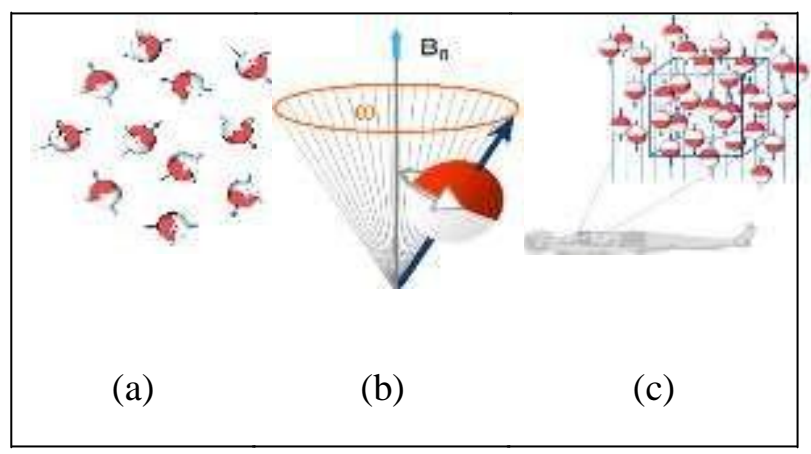

Gambar 1 (a) atom-atom hidrogen tersusun secara acak apabila tidak dikenai B0. (b) atom-atom hidrogen dikenai B0 dan melakukan presisi (disebut frekuensi larmor, ( $\omega$. (c) atom atom berpresesi sesuai dengan B0 terjadi pemisahan arah yaitu parallel dan antiparallel. [6]

Net magnetisasi (M) adalah jumlah vektor dari semua spin terkandung dalam dan akan disesuaikan sepanjang arah $\mathrm{z}$, yaitu arah $\mathrm{B}_{0}$. Sehingga Persamaan Bloch dapat dimodifikasi untuk mencerminkan perilaku net magnetisasi:

$$
\frac{2}{2} M=\hat{2} M \times B
$$

Fase Resonansi terjadi apabila pada saat fase presesi gelombang radio (RF) dipancarkan dan terjadi peristiwa perpindahan energi dari pulsa RF ke proton hidrogen, apabila pulsa RF memiliki frekuensi yang sama dengan frekuensi larmor atom hidorgen. Ketika medan magnet tambahan diterapkan terhadap variasi waktu, magnetisasi yang awalnya searah sumbu z yang sejajar dengan Bo akan menyimpang dari posisi kesetimbangan dan melakukan presesi sekitar medan magnet yang efektif $\mathbf{B}_{\mathbf{1}}$ ( (Gambar 2.2)

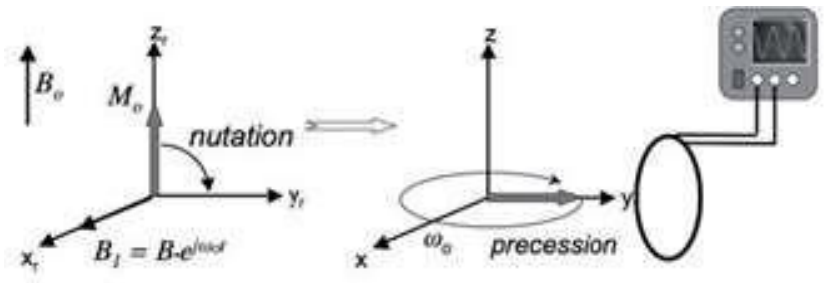

Gambar 2 Fase resonansi untuk mendeteksi suatu sinyal [7]
Pada Fase Resonansi gelombang RF akan di berhentikan (turn off). Setelah sinyal dengan frekuensi resonansi tersebut dihentikan, protonproton atom hidrogen secara perlahan kehilangan energinya dan mulai bergerak meninggalkan arah transversal menuju ke arah longitudinal dengan melepaskan energi yang diserapnya dari RF dalam bentuk gelombang elektromagnetik yang dikenal sebagai sinyal MRI. Fase ini disebut fase relaksasi [8]. Pada fase ini terdapat 2 fenomena waktu yaitu T1 dan T2. Besarnya dan proses waktu frekuensi T1 dan T2 sangat berpengaruh pada sinyal keluaran yang akan ditransformasikan sebagai kontras gambar, T1 akan menentukan magnetisasi longitudinal dalam arah sumbu $\mathrm{z}$ dan T2 akan mentukan magnetisasi transversal dalam arah sumbu $\mathrm{x}-\mathrm{y}$

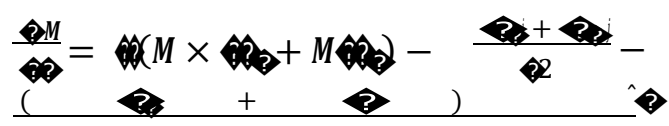

\section{(2.11)}

\subsection{Sequence Gradient Echo}

Dalam MRI, terdapat berbagai macam urutan pulsa (pulse sequence) yang tersedia untuk memperoleh gambar. Salah satu pencitraan sequence pulsa paling sederhana adalah gradien echo. Gradient Echo (GRE) adalah kelas dari urutan pulsa yang digunakan untuk scanning cepat [9]. GRE banyak digunakan dalam volume pencitraan 3D dan aplikasi lain yang membutuhkan kecepatan akuisisi.

\subsection{Parameter MRI}

Parameter kualitas pencitraan pada MRI adalah Signal to Noise Ratio (SNR) dan Contras to Noise Ratio (CNR). Kedua parameter ini yang akan menentukan pencitraan kualitas yang baik pada MRI. [10]

SNR merupakan perbandingan (rasio) amplitudo sinyal yang diterima oleh kumparan (coil) dengan amplitudo noise. SNR dipengaruhi oleh densitas proton, voxel volume, TR (Time Repetition) yaitu interval waktu antara pulsa RF awal dengan RF kedua, TE (Time Echo) yaitu waktu untuk echo (mencacat sinyal), sudut balik (flip angle), NEX (Number of Excitation) yaitu berapa kali data dicatat dalam K-space), rentang frekuensi (receive bandwidth) yaitu besar frekuensi dan koil receiver yaitu elemen pencatat sinyal [6]. 


\subsection{Artefak}

Artefak merupakan gangguan pada gambar yang diidentifikasi bukan suatu anatomi pada tubuh. [11]

Susceptibility Artifacts adalah artefak karena adanya bahan implan logam pada tubuh pasien dapat berakibat pada berubahnya bentuk organ, atau muculnya area hitam pada gambar. [12]

Chemical Shift artifacts adalah artefak yang terjadi karena adanya perbedaan ikatan atom hidrogen pada jaringan (terutama jaringan lunak dan lemak) [13]. Kedua artefak tersebut mengganggu diagnosis dan hasil citra yang tidak optimal dan dapat dikurangi dengan mengoptimalkan pengaturan nilai $\mathrm{BW}$ dan TE. [14]

\section{METODE PENELITIAN}

Penelitian ini dilaksanakan di Instalasi Rumah Sakit Umum Haji Surabaya dengan menggunakan pesawat MRI Siemens terhadap empat pasien dengan kisaran usia antara (22-60) tahun, dengan 4 pasien patologis. Sampel penelitian merupakan scanning pasien dengan pembobotan $\mathrm{T} 2$ Medic Axial MRI Shoulder, dengan menggunakan sequence Gradient Echo (GRE) dan masing - masing sampel diberikan variasi TE $16 \mathrm{~ms}, 20 \mathrm{~ms}$ dan BW $170 \mathrm{~Hz} / \mathrm{Px}, 190 \mathrm{~Hz} / \mathrm{Px}$ dan $210 \mathrm{~Hz} / \mathrm{Px}$ dengan variabel terkendali sebagai berikut; TR selama $700 \mathrm{~ms}$, FOV seluas $180>80$ $\mathrm{mm}$, Slice thickness sepanjang $4 \mathrm{~mm}$, Phase Encoding sebesar 256x256, NEX 1. Setiap scanning dalam satu variasi TE dan BW dihasilkan 19 gambar yang akan dipilih satu gambar terbaik yang menunjukkan jaringan-jaringan yang akan dianalisis besar sinyalnya. Jaringanjaringan tersebut adalah Humeral Bone, Glenoid Labrum, Fluid, Fat dan dilakukan terhadap Artefak serta noise background. Jaringan dan artefak dianalisis besarnya sinyal dengan teknik Region of Interest (ROI).

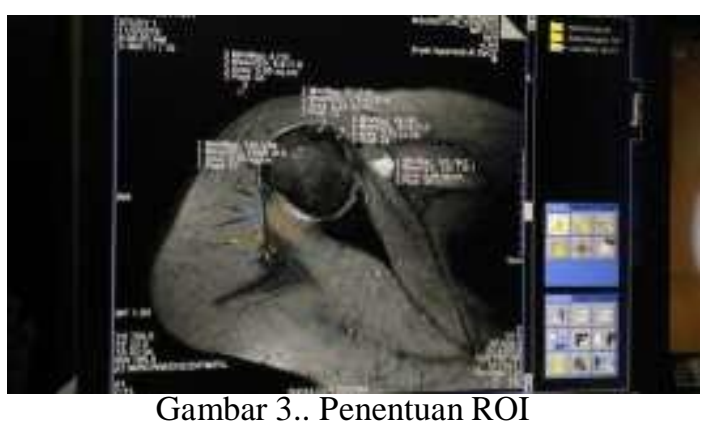

Teknik ROI digunakana para peneliti dalam pengambilan sinyal pada suatu daerah yang mendapatkan perhatian khusus sehinga area tersebut dapat mewakili jaringan yang ada Syarat melakukan ROI adalah dengan mengambil suatu daerah dengan luas penampang dengan standrat deviasi yang sekecil mungkin. Daerah yang di ROI harus mempunyai intensitas yang homogen. [15]

\section{ANALISIS DATA}

Analisis data terbagi atas analisis nonstatistik dan analisis statsitik. Analisisi nonstatistik digunakan pada data kualitatif yaitu data yang tersusun bukan berdasarkan angka. Analisis non-statitsik ini biasanya diolah dan dianalisis berdasarkan subtansinya. Analisis statistik menggunakan data kuantitatif yaitu data yang berupa angka kemudian dilakukan uji statistic dengan menggunakan program SPSS.

ROI pada jaringan dilakukan dengan membuat area untuk mengetahui besar nilai mean pada satu gambar yang dipilih (Gambar 4a ). Mean tersebut menunjukkan besar sinyal (S) pada jaringan yang akan dianalisis untuk mengetahui nilai SNR dan CNR.

ROI pada background dilakukan dengan membuat area diluar jaringan, area tersebut dibuat lebih besar dari ROI jaringan, ROI background dipilih besar nilai standrat deviation (SD) nya (Gambar 4b) Pengambilan ukuran lingkaran yang besar dikarenakan area background memiliki area yang cukup besar sehingga besar sinyalnya dapat mewakili area yang lain. Background tersebut merupakan noise $(\mathrm{N})$ yang akan dianalisis secara kuantitatif untuk mendapatkan SNR dan CNR.

ROI pada artefak dilakukan pada gambar yang memunculkan artefak. Artefak pada jaringan terjadi karena tidak cukup waktu bagi jaringan pada saat pencatatan sinyal. Artefak terjadi karena banyak hal seperti kesalahan pada saat pasien bergerak, ataupun kesalahan bagi radiogrefer pada saaat screening 
pasien, sehingga terdapat benda logam yang menempel pada tubuh pasien.

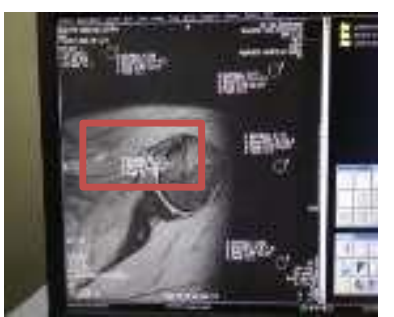

(a) ROI jaringan

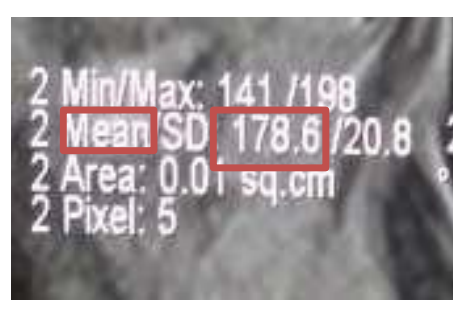

Diambil nilai Mean

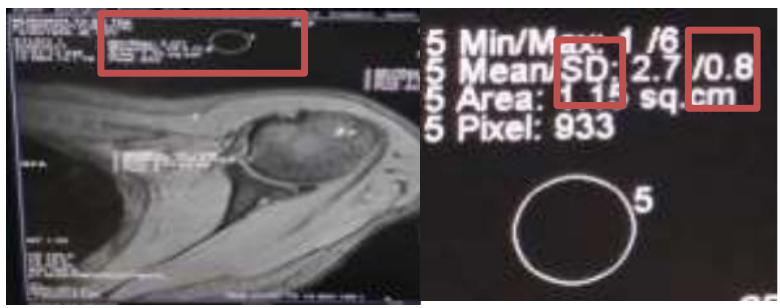

(b) ROI Background diambil 4 kali pada satu citra

ROI background diambil standar deviasi (SD)

Gambar 4. Sampel analisis ROI Pemeriksaan MRI Shoulder Dengan Variasi TE dan BW

Berdasarkan Gambar 4 didapatkan nilai Min/Max, Area dan Pixel. Nilai Min/Max merupakan besar intensitas sinyal dari nilai grayscale yang di angkakan oleh komputer dari terendah (minimum) sampai tertinggi (maksimum). Area merupakan luas daerah ROI pada jaringan yang akan di identifikasi dengan satuan sq.cm. Pixel merupakan banyaknya jumlah pixel, pada gambar tersebut didapatkan jumlah pixel sebanyak 933.

Analisis secara kuantitatif pada suatu gambar dengan variasi TE dan BW dilakukan dengan teknik ROI pada setiap jaringan dan background yang akan dianalisis besar nilai sinyal $(\mathrm{S})$ dan noise $(\mathrm{N})$.

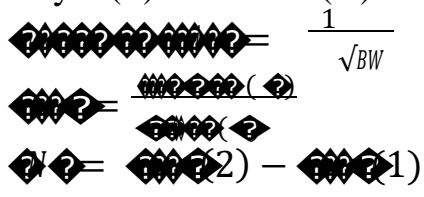

\section{Hasil dan Pembahasan}

Telah diperoleh 1 citra yang terbaik dari 19 citra dengan kombinasi variasi TE dan BW, kemudian dilakukan analisis SNR dan CNR dengan mengambil nilai mean yang merupakan sinyal dari jaringan Humeral Bone, Glenoid Labrum, Fluid, Fat dan dilakukan pengambilan nilai SD yang merupakan noise terhadap background. Jaringan dan banckgorund lianalisis besarnya sinyal dengan teknik Region of Interest (ROI).

\section{Analisis Signal to Noise Ratio (SNR)}

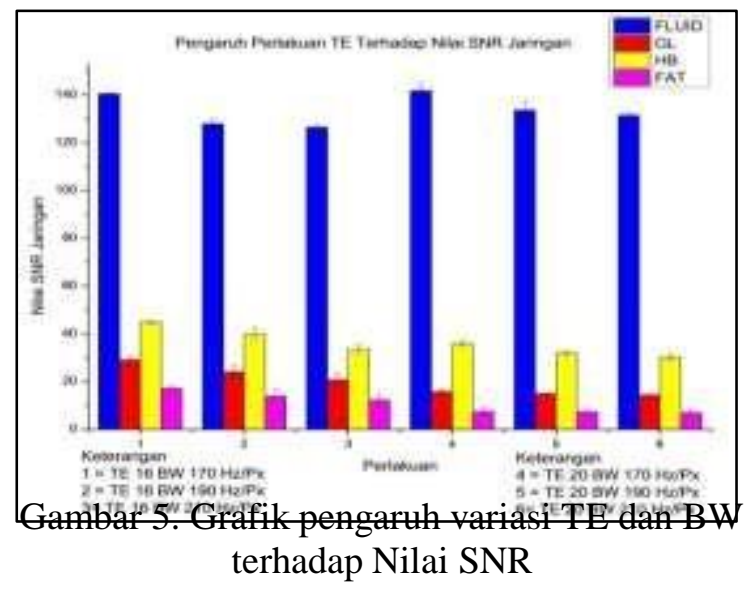

Dari Gambar 5 dapat dilihat bahwa semakin besar nilai TE dan BW maka nilai SNR turun pada setiap jaringan yaitu fluid, Glenoid Labrum (GL), Humeral Bone (HB), dan Fat.

Dari hasil data dan penelitian menunjukkan bahwa pengaruh variasi TE dan BW terhadap nilai SNR tidak stabil atau linier karena setiap variasi yang diberikan menghasilkan SNR tertentu. Pengaruh kedua variasi tersebut menghasilkan perubahan nilai SNR, hal ini dipengaruhi oleh struktur molekul atom hidrogen pada setiap jaringan, jika pada jaringan tersebut mempunyai atom hidrogen yang banyak maka jaringan tersebut mempunyai SNR yang tinggi. Faktor usia juga mempengaruhi hasil citra MRI karena komposisi atom hidrogen yang mulai berkurang pada setiap jaringan sehingga hasil SNR didapatkan rendah karena kurangnya atom hidrogen pada suatu jaringan. 


\subsection{Analisis Contrast to Noise Ratio (CNR)}

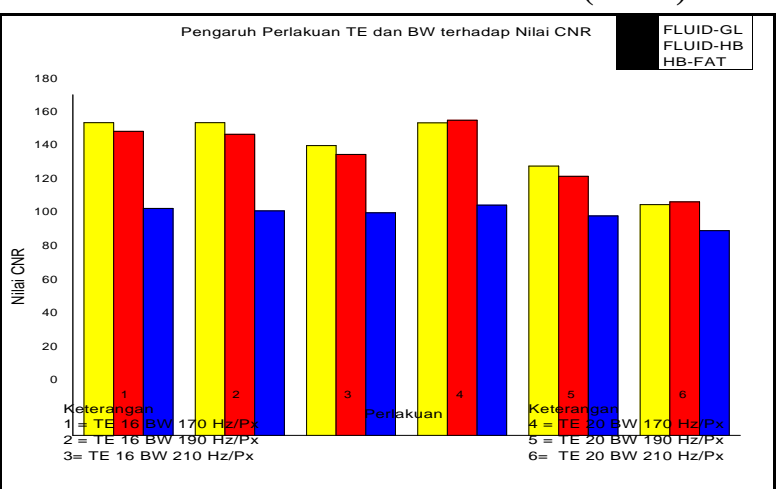

Gambar 6. Grafik pengaruh variasi TE dan BW terhadap Nilai CNR

Dari Gambar 6 terlihat bahwa semakin besar nilai TE dan $\mathrm{BW}$, nilai CNR tiap 2 jaringan yang berdekatan menunjukkan penurunan. Jika TE diperbesar maka didapatkan CNR yang tinggi. Tetapi kenaikan nilai BW maka CNR mengalami penurunan.

Dari hasil data penelitian menunjukkan bahwa pengaruh variasi TE dan BW memberikan hasil yang linier terhadap nilai CNR. Pada jaringan tertentu dibutuhkan kontras yang tinggi untuk membedakan adanya patologis dengan jaringan disekelilingnya. Pada penelitian ini menjadi fokus utama adalah 2 jaringan yaitu Fluid dan Glenoid Labrum (GL), kedua jaringan tersebut terletak berdekatan sehingga dapat dihitung perbedaan kontrasnya, kebanyakan patologis didaerah bahu yang sering menjadi indikasi pemeriksaan MRI Shoulder terletak pada area GL. Pada kedua jaringan tersebut memiliki densitas yang berbeda, GL memiliki densitas proton yang kecil sehingga kurang rentan terhadap resonansi radio frekuensi sehingga memberikan signal yang rendah (hypointense). Sedangkan fluid peka terhadap resonansi radio frekuensi sehingga memberikan kontribusi besar pada citra (hyperinterse). Perbandingan dari kedua jaringan tersebut dapat digunakan untuk patokan pengambilan nilai CNR yang optimal.

\subsection{Hubungan Pengaruh Variasi TE dan BW terhadap Nilai SNR dan CNR}

Berdasarkan nilai yang telah didapatkan dari hasil perhitungan secara kuantitatif dapat diketahui hubungan antara SNR dan CNR terhadap kedua variasi yang diberikan. Hubungan SNR dan CNR ditunjukkan pada Gambar 7

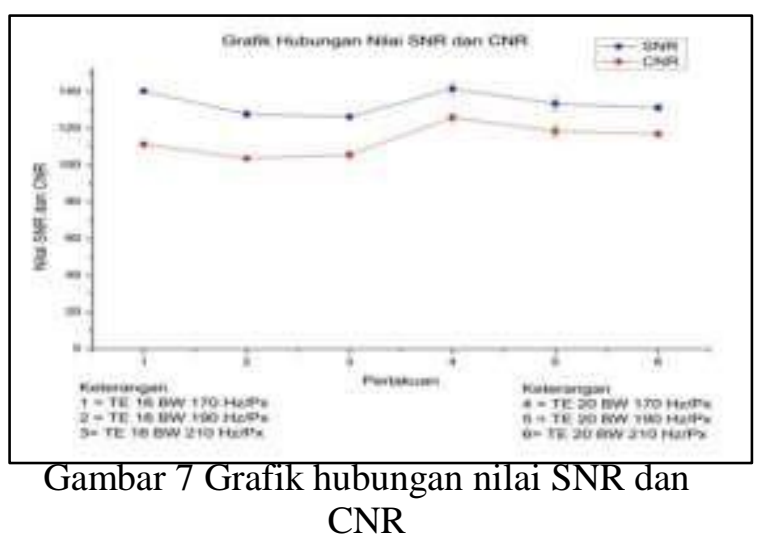

Pada grafik diatas terdapat perbedaan hasil antara SNR dan CNR akibat adanya perubahan TE, dimana TE kecil akan menghasilkan SNR yang tinggi begitu sebaliknya, tetapi ketika TE semakin besar maka CNR semakin meningkat. Berbeda dengan bandwidth jika bandwidth semakin besar maka SNR semakin tinggi, jika nilai bandwidth diperbesar maka CNR sementara jika BW semakin besar maka CNR akan semakin menurun. Tetapi pada penelitian ini, tidak dapat dipisahkan antara variasi TE dan BW yang menghasilkan suatu nilai SNR maupun CNR. Sehingga pada penelitian ini dilihat pengaruh antara kombinasi variabel TE dan BW.

\subsection{Analisis Pengaruh Variasi TE dan BW terhadap Artefak}

Pada penelitian ini terdapat 2 artefak yang dianalisis, yaitu adanya artefak Chemical Shift dan susceptibility artifacts. Susceptibility Artifacts adalah artefak karena adanya bahan magnet atau implant logam pada tubuh pasien dapat berakibat pada munculnya area hitam pada organ sehingga dapat merusak suatu image, dapat dilihat pada Gambar 8.

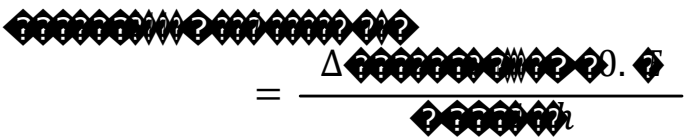



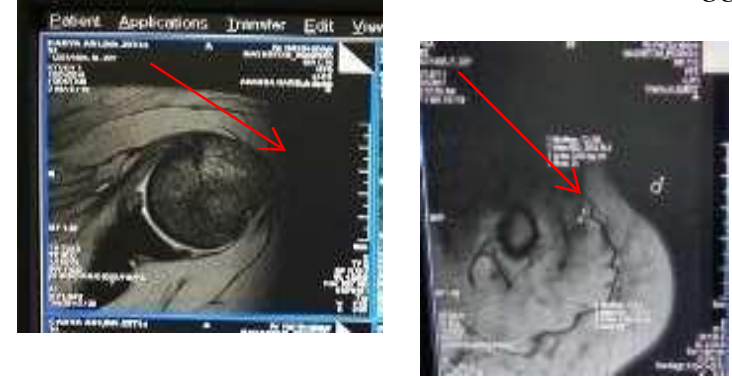

Gambar 8. Pengaruh benda magnetik pada suatu image

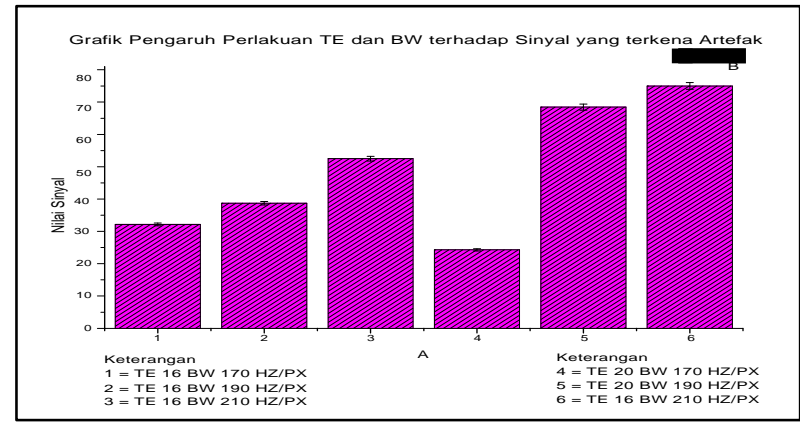

Gambar 9. Pengaruh Variasi TE dan BW Terhadap Sinyal Jaringan akibat adanya artefak

Berdasarkan Gambar 9, pertama peneliti meninjau dari pengaruh variasi $\mathrm{BW}$, dimana BW semakin rendah maka rentang BW akan semakin pendek sehingga nilai pencatatan signalnya akan semakin sempit. Oleh sebab itu, tingkat grayscale yang dihasilkan akan semakin sempit sehingga artefak logam (Suceptibilty artifact) yang terdeteksi dengan sinyal hitam karena loss signal akan semakin sedikit. Ketika rentang frekuensinya (BW) lebar maka gray scale kehitaman tersebut akan di rata-ratakan pada frekuensi yang lebih lebar. Bandwidth yang besar maka sinyal loss tersebut (derajat kehitamannya) akan semakin kecil.

Kedua, peneliti meninjau tentang pengaruh TE, dimana TE merupakan lamanya proses pencatatan signal pada amplitudo tertinggi dalam rentang Time repetition (TR). Dimana semakin lama pencatatan sinyal maka akan semakin mengurangi artefak Suseptibility atau kehitaman akan semakin tinggi karena susceptibility tersebut akan semakin tercatat sinyalnya oleh pencatatan TE yang lebih

sehingga semakin memperjelas kontras kehitaman karena logam tersebut.

Chemical Shift terjadi karena adanya perbedaan magnetic shielding pada jaringan (terutama jaringan lunak dan lemak). Tergambar sebagai batas berwarna hitam pada sisi luar organ. Chemical Shift dapat terlihat pada penggunaan TE yang besar dan Bandwidth yang besar. Besarnya Chemical Shift dapat dihubungkan dengan persamaan

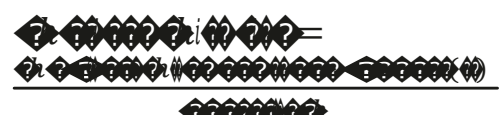

Grafik Pengaruh Perlakuan TE dan BW terhadap Sinyal yang terkena Artefak

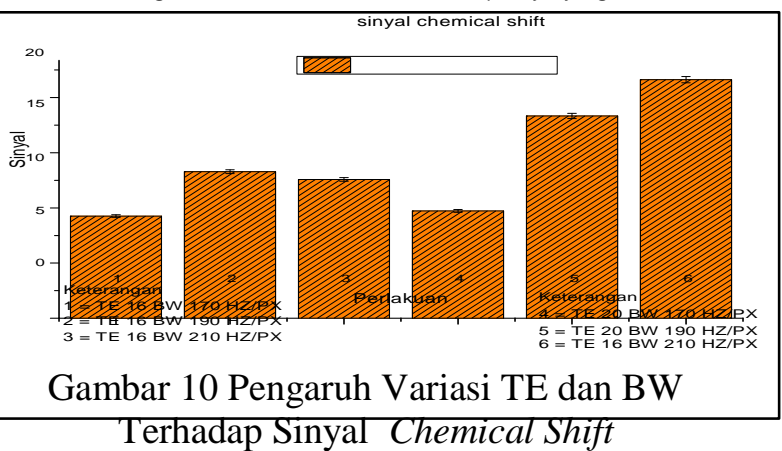

Berdasarkan Gambar 10, diketahui bahwa ketika nilai TE naik maka Chemical Shift akan cenderung semakin menurun, hal ini sesuai dengan teori bahwa adanya perbedaan ikatan atom hidrogen antara lemak dan jaringan lunak akan menyebabkan sinyal (kontras) menjadi tumpang tindih (overlap) sehingga memunculkan artefak. Kenaikan TE menghasilkan perbedaan precessional frekuensi antara fat dan water yang semakin lebar dan terlihat semakin jelas beda sinyalnya, sehingga analisis terhadap patologis menjadi akurat karena adanya artfeak dapat dikurangi.

\subsection{Penetuan Nilai Optimal Variasi TE dan BW Terhadap Nilai Artefak}

Penentuan nilai optimal pada kedua variasi tersebut diperoleh dengan membuat grafik secara terpisah antara variabel TE dengan Artefak dan BW dengan Artefak

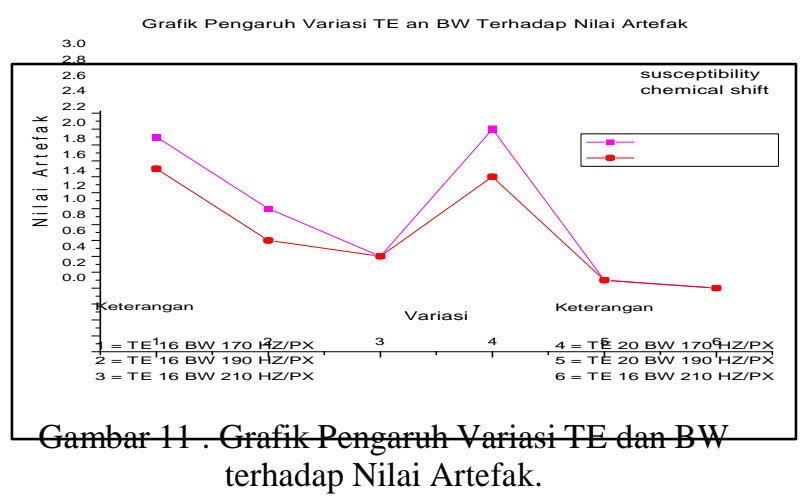

Dari grafik diatas dapat dilihat bahwa nilai optimal yang menunjukkan succepbility 
artifact dan Chemical Shift artifact paling rendah pada TE $20 \mathrm{~ms}$ dengan kombinasi BW $210 \mathrm{~Hz} / \mathrm{Px}$. Pada nilai tersebut artefak semakin menurun, sehingga ketika semakin rendah nilai artefak, maka sinyal anatomi yang dinilai dapat dilihat dengan jelas yang terdapat pada suatu citra. Semakin rendah nilai artefak tersebut maka dokter dapat dengan mudah menilai patologis, sehingga tidak salah dalam menegakkan diagnosa.

\subsection{Penentuan Nilai Optimal Variasi TE dan BW terhadap Nilai CNR, Chemical Shift dan Susceptibility Artifacts}

Berdasarkan Gambar 7 dan 11 dapat ditentukan nilai optimal untuk CNR dan (dua) artefak tersebut. Dimana pada gambar 7 yaitu grafik pengaruh antara TE dan BW terhadap nilai CNR diketahui bahwa pada variasi TE 20 ms dan BW $170 \mathrm{~Hz} / \mathrm{Px}$ terlihat adanya kenaikan kualitas kontras citra. Sedangkan pada gambar 9 yaitu grafik pengaruh antara TE dan BW terhadap artefak diketahui bahwa pada variasi TE $20 \mathrm{~ms}$ dan $\mathrm{BW} 210 \mathrm{~Hz} / \mathrm{Px}$ menunjukkan penurunan nilai artefak. Kemudian pengaruh TE dan BW terhadap CNR dan Artefak dianalisis menggunakan uji statistik untuk menentukan beda signifkan. Diketahui bahwa pada uji statistik menggunakan uji multivariat pada jaringan fluid - humeral bone dihasilkan nilai sig 0.319 sehingga tidak terdapat beda bermakna. Oleh karena itu peneliti, mengkorelasikan hasil data lapangan dan uji statistik dengan teori yang ada sebelumnya diapatkan pada TE $20 \mathrm{~ms}$ dan BW $210 \mathrm{~Hz} / \mathrm{Px}$ dapat menurunkan adanya artefak karena Chemical Shift dan susceptibility.

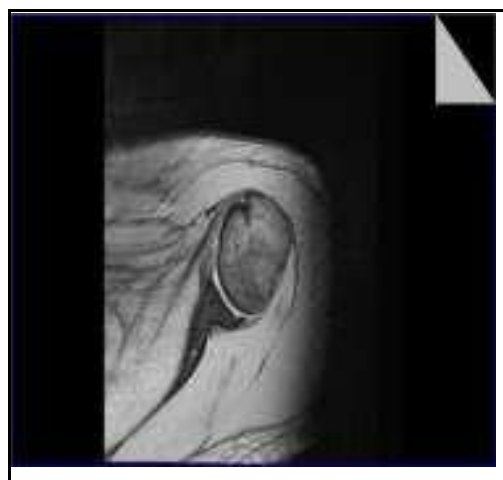

TE 16 BW 170 HZ/PX

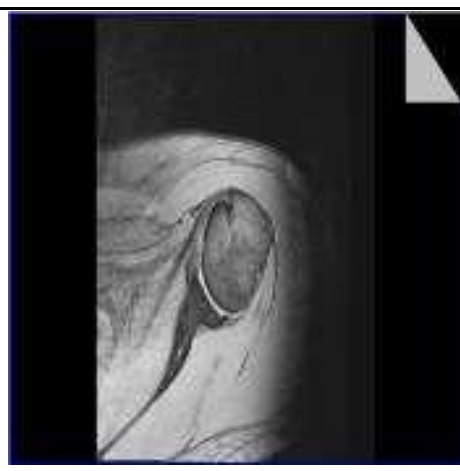

TE 16 BW 190 HZ/PX

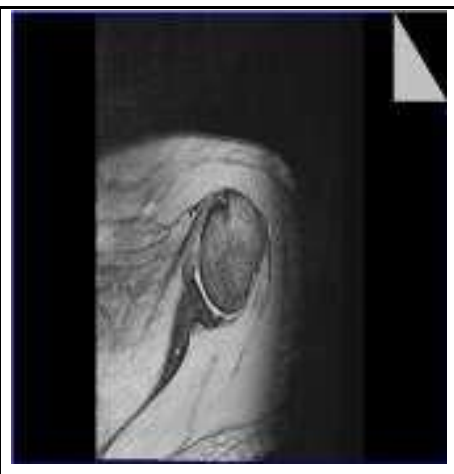

TE 16 BW 210 HZ/PX

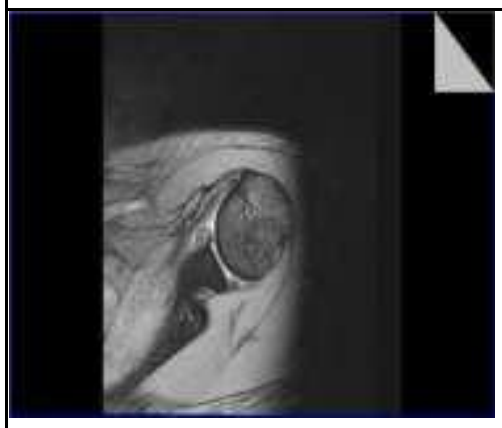

TE 20 BW 170 HZ/PX

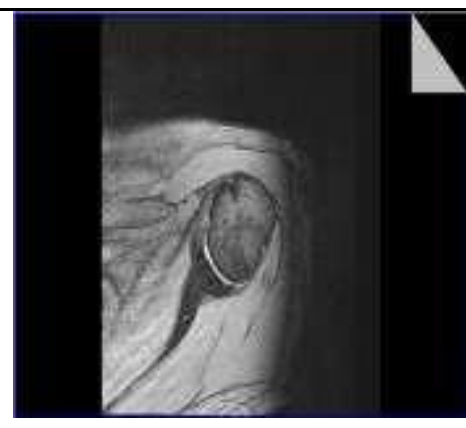

TE 20 BW 190 HZ/PX

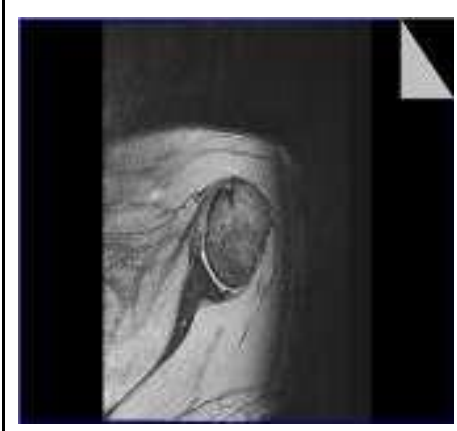

TE 20 BW 210 HZ/PX

Foto Hasil Pemeriksaan dengan variasi TE dan BW

(terlihat adanya artefek dikarenakan benda logam) 


\section{KESIMPULAN}

Berdasarkan penelitian yeng telah dilakukan, maka dapat diambil kesimpulan sebagai berikut;

1. Variasi Time Echo dan bandwidth berpengaruh signifikan terhadap nilai SNR dan CNR pada hasil citra T2 Axial Gradient Echo MRI Shoulder. Pengaruh kedua variasi tersebut adalah semakin kecil nilai TE dan BW didapatkan SNR yang meningkat. Jika TE diperbesar maka didapatkan CNR yang meningkat.

2. Kualitas citra optimal yang dapat menghasilkan keadaan patologis ditentukan dengan meningkatnya nilai CNR dan nilai artefak yang menurun. Sehingga Pada penelitian ini kombinasi antara 2 variabel tersebut dapat menentukan citra optimal pada TE $20 \mathrm{~ms}$ dan BW 210 $\mathrm{Hz} / \mathrm{Px}$.

\section{DAFTAR PUSTAKA}

[1] D. E. G. A. Rani, "Adln perpustakaan universitas airlangga," 2016.

[2] A. Tanjung, A. Prastowo, and W. Setiabudi, "KORELASI NILAI TIME REPETITION ( TR ) DAN TIME ECHO ( TE ) TERHADAP SIGNAL TO NOISE RATIO ( SNR ) PADA CITRA MRI," vol. 16, no. 4, pp. 103-110, 2013.

[3] S. P. Dita and H. D. Yanuarita, "Studi Apparent Diffusion Coefficient dari Hidrogel PVA Pada MRI dan Korelasinya dengan Hasil Pengukuran Konsistensi Menggunakan Penetrometer," 2011.

[4] E. Hahn and R. Ernst, "MAGNETIK RESONANS INTI ( MRI )," pp. 164, 2016.

[5] M. N. dan E. H. Josepa ND

Simanjuntak, "Studi Analisis Echo Train Length Dalam K- Space Serta Pengaruhnya Terhadap Kualitas Citra Pembobotan T2 Fse Pada MRI 1,5 T," vol. 17, no. 1, pp. 7-12, 2014.

[6] C. Wesbrook, Handbook MRI Technique Fourth Edition. This edition first published 2014 (C) 2014 by John Wiley \& Sons, Ltd., 2014.

[7] D. . Dance, S. Christofides, A. D. . Maidment, I. . Mclean, and K. . Ng, "Diagnostic Radiology Physics," Diagnostic Radiol. Phys. A Handb. Teach. Students, pp. 209-235, 2014.

[8] W. Setia and C. Anam, "Upaya peningkatan kualitas citra mri dengan pemberian media kontras," vol. 16, no. 1, pp. 9-14, 2013.

[9] S. Suzuki and O. Sakai, "Combined volumetric T 1 , T 2 and secular- T 2 quantitative MRI of the brain: agerelated global changes ( preliminary results )," vol. 24, no. August 2005, pp. 877-887, 2006.

[10] D. Rochmayanti, T. S. Widodo, and I. Soesanti, "Analisis Perubahan Parameter Number of Signals Averaged ( NSA ) Terhadap Peningkatan SNR dan Waktu Pencitraan pada MRI," Jnteti, vol. 2, no. 4, pp. 37-45, 2013.

[11] and D. I. H. Andrew J. Dwyer, Richard H.Knp, "frequency shift artifacts in mr imaging." 1985.

[12] D. R. Lide, "Magnetic susceptibility of the elements and inorganic compounds," Handb. Chem. Phys., pp. 130-135, 2005.

[13] M. N. Hood, V. B. Ho, and J. G. Smirniotopoulos, "Chemical Shift :

The Artifact and Clinical Tool Revisited 1,"pp. 357-371, 1999.

[14] J. Graessner, "Bandwidth in MRI?," Siemens.Com, vol. 2, pp. 3-8, 2013.

[15] J. Dahjono and M. R. Sativa, "ISSN 2356-301X OPTIMISASI FIELD OF VIEW ( FOV ) TERHADAP KUALITAS CITRA PADA T2WI FSE MRI LUMBAL SAGITAL FOV ( FIELD OF VIEW ) OPTIMIZATION TO IMAGE QUALITY ON T2WI FSE SAGITAL LUMBAR MR IMAGING Fatimah : Optimisasi Field of View ... Fatimah : Optimisasi," vol. 1, no. 1, pp. 1-5. 